Igor Lukić1, Nevena Ranković2, Dragica Ranković ${ }^{3}$

\title{
RISK ASSESSMENT FOR DIABETES TYPE 2 CONDITIONS FOR NATURE IN NUTRITION IN ADOLESCENTS
}

Apstract: This paper will present the results of a study on dietary habits in adolescents. The high school or adolescent era is a time of great physical and psychological changes, which cause instability and oscillations in the mood and behavior of high school students. Results obtained by interviewing secondary school students about eating habits and results obtained using a standardized questionnaire for the risk of type 2 diabetes were analyzed using a reliable statistical tool IBM SPSS Statistical, which offers a range of reliable analyzes and statistical tests. Previous research has shown that for each person with type 2 diabetes, one person finds out who does not know it. Discovery of pre-diabetes, in new potential patients, is necessary at the earliest age, when a number of factors affect lifestyles, such as irregular nutrition and obesity, physical inactivity, stress, and others become important for the development of this disease. Detection of risk levels in potential patients is important for both the individual and public health, and everyday clinical practice. After determining the degree of risk for a particular sample, a set of measures for a particular adolescent population will be recommended, so that the disease does not occur, or its onset will move for a later period of life.

Keywords: nutrition, diabetes type 2, adolescente, risk factors.

\footnotetext{
Igor Lukić, PhD student, Faculty of Medicine, Kragujevac.

2 Nevena Ranković, Assistant at the Department of Computer Science, Faculty of Sciences, Novi Sad.

Dragica Ranković, Medical School „Dr Miša Pantić“, Valjevo.
} 


\section{INTRODUCTION}

Type 2 diabetes is an insulin-independent type of diabetes, in which insulin secretion is reduced (1). It can occur at any age, but most commonly in obese people. In the last decade, with significant numbers of adolescents, there is extreme obesity, mostly caused by improper nutrition, insufficient physical activity, stress, etc. (2) Along with the increase in obesity, there is an increase in type 2 diabetes, heart disease, stroke, diabetes retinopathy, which has an effect on vision, kidney failure, resulting in dialysis, poor circulation in the most commonly lower extremities, which can be caused by amputations and many other diseases (3), (4), (5).

Type 2 diabetes, which previously had the highest incidence in the elderly, begins to increase exponentially and even in children, especially in the period of puberty or adolescence (6), (7). In the last decade, with a significant number of adolescents, there is extreme obesity, mainly caused by irregular nutrition, insufficient physical activity, stress, etc. (8) In addition to the increase in obesity, type 2 diabetes also occurs (9), (10). Many studies in the country and abroad show that by reducing the intake of certain foods, weight can be reduced, and hence the risk of this disease (11), (5).

\section{Structure of the sample}

A total of 318 secondary school students from the Kolubara district participated in the research that will be presented in this paper. The structure of the sample consisted of 145 (45.6\%) male students and 173 (54.4\%) female students. Observed by the classes currently taught, the structure of students consists of: $71(22.3 \%)$ students of the first year, $89(28.0 \%)$ students of the second year, 79 (24.8\%) students of the third year and $79(24.8 \%)$ students of the fourth year. The center from which students come from: the urban environment 113 (35.5) students, suburban 114 (35.8\%) students and the rural environment 91 (28.7) pupils. There are no statistically significant differences in the gender, class, or environment from which they come (Table 1).

Table 1. Student sample structure

\begin{tabular}{|c|c|c|c|c|c|}
\hline \multicolumn{6}{|c|}{ Student sample structure } \\
\hline & & $\begin{array}{c}\text { Frequency } \\
\%\end{array}$ & Percent & CS & $\mathrm{CS}(\mathrm{p})$ \\
\hline \multirow[b]{2}{*}{ Gender } & male & 145 & 45.6 & \multirow{2}{*}{2.465} & \multirow[b]{2}{*}{0.116} \\
\hline & female & 173 & 54.4 & & \\
\hline \multirow{4}{*}{ Class } & 1. class & 71 & 22.3 & \multirow{4}{*}{2.050} & \multirow{4}{*}{0.562} \\
\hline & 2. class & 89 & 28.0 & & \\
\hline & 3. class & 79 & 24.8 & & \\
\hline & 4. class & 79 & 24.8 & & \\
\hline
\end{tabular}




\begin{tabular}{|c|c|c|c|c|c|}
\hline \multicolumn{6}{|c|}{ Student sample structure } \\
\hline & & $\begin{array}{c}\text { Frequency } \\
\%\end{array}$ & Percent & CS & $\mathrm{CS}(\mathrm{p})$ \\
\hline \multirow{3}{*}{ Environment } & urban & 113 & 35.5 & \multirow{3}{*}{3.489} & \multirow{3}{*}{0.175} \\
\hline & suburban & 114 & 35.8 & & \\
\hline & rural & 91 & 28.7 & & \\
\hline
\end{tabular}

\section{Subject research}

In the first part of the study, students completed an anonymous questionnaire, which discusses their eating habits and the consumption of certain foods and beverages. The first part of the questionnaire, besides basic information such as gender, the class that they currently attend and the environment from which they come, contains a question about their assessment, opinion on the regularity of their nutrition. In the second group of questions, the students evaluated the average consumption of these types of foods such as fish, meat, milk and dairy products, bread, pastry and pastry, fruits, vegetables, cakes, sweets, water, fruit juices, energy, and aerated drinks. The third group of questions was issues related to the existence of health problems or hereditary diseases, keeping diets, their opinions and attitudes about diet, whether they necessarily have breakfast and generally affect food on health(6).

The second part of the study looked at the risk of type 2 diabetes. In a study of 318 students, 111 students volunteered to fill in an online standardized questionnaire, $48(43.2 \%)$ male students and $63(56.7 \%)$ female students. Since most students do not know the BMI value, a short online questionnaire was first made for calculating it, from which it is precisely possible to get the exact value. The standardized questionnaire for the type 2 diabetes risk contains 8 questions that students who want to answer can ask. The "pol" option is added to it, in order to compare student responses according to this criterion. The sum of the points obtained from the response provides a risk assessment of the onset of diabetes type 2 (7).

\section{Methodological remarks}

The results obtained using the questionnaire were analyzed using a reliable statistical tool IBM SPSS Statistical, which offers a range of reliable analyzes and statistical tests. Students' responses were on the 5-point Likert scale: (1 means very bad, 2 means bad, 3 means satisfactory, 4 means good, 5 is very good), Kruskal Wallis's H Test KW (H) and its significance KW (p) was used for this type of questions. To analyze the answer questions Yes/Neutral/No, the Chi-Square test (CS) and its significance CS (p) was used. For the analysis of the obtained results in the online 
test for the risk of diabetes type 2 were used: Mean and One-Way ANOVA Test for comparing the answers of male and female students. (12), (13), (14).

Research hypotheses:

H1: In adolescents aged 14 to 18 years, there are no statistically significant differences in consuming different foods by gender, age, or environment in which live.

H2: Small percentage (less than $15 \%$ ) of adolescents has a risk of diabetes type 2, observed by sex of respondents.

\section{Analysis of the obtained results}

The students gave their opinion on their own nutrition to the first question asked. $12.7 \%$ of male students believe that it is properly fed, the vast majority of $69.0 \%$ of pupils are properly fed, while $18.3 \%$ think it is fed incorrectly. $12.5 \%$ of female students think that it is properly fed, the vast majority of $78.5 \%$ of students are fed properly, while $9.0 \%$ think that they are feeding incorrectly. There are no statistically significant differences in students' responses to gender (Table 2).

Table 2. Students' opinions about their nutrition by gender, class, and environment from which they come

\begin{tabular}{|c|c|c|c|c|c|c|}
\hline \multicolumn{7}{|c|}{ Students' opinions about their nutrition by gender, class, and environment from which they come } \\
\hline & & Yes $\%$ & Neutral \% & No $\%$ & $\mathrm{KW}(\mathrm{H})$ & KW(p) \\
\hline \multirow{2}{*}{ Gender } & male & 12.7 & 69.0 & 18.3 & \multirow{2}{*}{2.538} & \multirow[b]{2}{*}{0.111} \\
\hline & female & 12.5 & 78.5 & 9.0 & & \\
\hline \multirow{4}{*}{ Class } & 1. class & 11.3 & 70.4 & 18.3 & \multirow{4}{*}{3.376} & \multirow{4}{*}{0.337} \\
\hline & 2. class & 20.9 & 65.1 & 14.0 & & \\
\hline & 3. class & 9.0 & 82.0 & 9.0 & & \\
\hline & 4. class & 8.0 & 80.0 & 12.0 & & \\
\hline \multirow{3}{*}{ Environment } & urban & 13.7 & 75.2 & 11.1 & \multirow{3}{*}{0.810} & \multirow{3}{*}{0.667} \\
\hline & suburban & 12.7 & 72.7 & 14.6 & & \\
\hline & rural & 10.0 & 74.4 & 14.6 & & \\
\hline
\end{tabular}


First-class students, total of $11.3 \%$ think that it is properly fed, partly properly fed by a large majority of $70.4 \%$ of students, while $18.3 \%$ think it is fed incorrectly. Second-class students $20.9 \%$ think that they are properly fed, the vast majority of $65.1 \%$ of students are fed partly properly, while $14.0 \%$ think that they are feeding incorrectly. Third-class students, total of $9.0 \%$ believe that they are properly fed, the vast majority of $82.0 \%$ of students are fed partly properly, while $9.0 \%$ think that they are feeding incorrectly. Students of the fourth class, total od $8.0 \%$ believe that it is properly fed, the vast majority of $80.0 \%$ of students are partially properly fed, while $12.0 \%$ think that they are feeding incorrectly. There are no statistically significant differences in pupils' responses to gender (Table 2).

Students from the urban environment, $13.7 \%$ of them think that they are properly fed, the vast majority of $75.2 \%$ of the students are partially properly fed, while $11.1 \%$ think that they are feeding incorrectly. About $12.7 \%$ of students in the suburban environment think that the majority of $72.7 \%$ of students are properly fed, while $14.6 \%$ believe that they are fed incorrectly. Around $10.0 \%$ of rural school students think that they are properly fed, the vast majority of $74.4 \%$ of students are fed partly properly, while $14.6 \%$ think that they are feeding incorrectly. There are no statistically significant differences in students' responses to gender (Table 2).

The second part of the questionnaire refers to students' habits in consuming certain groups of foods. By analyzing the responses of male (2.71) and female (2.66) students, there are no statistically significant differences in the consumption of fish and fish products. There are no statistically significant differences in the answers of the students of the first class (2.71), the second class(2.60), the third class (2.75) and the fourth class (2.68). In the answers from students from the urban environment (2.54), from the suburban environment (2.93), and the rural environment (2.53) there are statistically significant differences (Table 3 ).

Table 3. Answers of students about consuming fish and fish products by gender, class, and environment from which students come

\begin{tabular}{|c|c|c|c|c|}
\hline \multicolumn{5}{|c|}{ How much do you consume fish and fish products? } \\
\hline \multirow{3}{*}{ Gender } & & Mean & KW(H) & KW(p) \\
\hline \multirow{4}{*}{ Class } & male & 2.71 & & \\
\cline { 2 - 3 } & female & 2.66 & 0.252 & 0.615 \\
\hline \multirow{3}{*}{} & 1. class & 2.71 & & \\
\cline { 2 - 3 } & 2. class & 2.60 & \multirow{2}{*}{1.182} & \multirow{2}{*}{0.757} \\
\cline { 2 - 3 } & 3. class & 2.75 & & \\
\cline { 2 - 5 } & 4. class & 2.68 & & \\
\hline
\end{tabular}




\begin{tabular}{|c|c|c|c|c|}
\hline \multirow{2}{*}{ Environment } & urban & 2.54 & \multirow{2}{*}{} \\
\cline { 2 - 3 } & suburban & 2.93 & \multirow{2}{*}{9.787} & $\mathbf{0 . 0 0 7}$ \\
\cline { 2 - 3 } & rural & 2.53 & & \\
\hline
\end{tabular}

By analyzing the answers of male students (3.24) and female students (2.87), there are statistically significant differences in the consumption of meat and meat products. In the answers of the students of the first class (3.01), the second class (2.94), the third class (3.16) and the fourth class (3.04) there are no statistically significant differences. In the answers of students from the urban environment (3.08), there are no statistically significant differences from the suburban environment (2.99) and the rural environment (3.04) (Table 4).

Table 4. Answers of students about consuming meat and meat products by gender, class, and environment from which students come

\begin{tabular}{|c|c|c|c|c|}
\hline \multicolumn{5}{|c|}{ How much do you consume meat and meat products? } \\
\hline & & Mean & $\mathrm{KW}(\mathrm{H})$ & $\mathrm{KW}(\mathrm{p})$ \\
\hline \multirow[b]{2}{*}{ Gender } & male & 3.24 & \multirow[b]{2}{*}{9.667} & \multirow[b]{2}{*}{0.002} \\
\hline & female & 2.87 & & \\
\hline \multirow{4}{*}{ Class } & 1. class & 3.01 & \multirow{4}{*}{2.410} & \multirow{4}{*}{0.492} \\
\hline & 2. class & 2.94 & & \\
\hline & 3. class & 3.16 & & \\
\hline & 4. class & 3.04 & & \\
\hline \multirow{3}{*}{ Environment } & urban & 3.08 & \multirow{3}{*}{0.211} & \multirow{3}{*}{0.900} \\
\hline & suburban & 2.99 & & \\
\hline & rural & 3.04 & & \\
\hline
\end{tabular}

By analyzing the answers of male students (3.74) and female students (3.78), there are no statistically significant differences in the consumption of milk and dairy products. In the answers of students of the first class (3.80), second class (3.74), third class (3.85) and fourth class (3.67) there are no statistically significant differences. There are no statistically significant differences in the answers of students from the urban environment (3.79), from the suburban environment (3.68), and the rural environment (3.85). (Table 5). 
Table 5. Answers of students about consuming milk and dairy products according to the gender, class and environment from which students come

\begin{tabular}{|c|c|c|c|c|}
\hline \multicolumn{5}{|c|}{ How much do you consume milk and dairy products? } \\
\hline & & Mean & $\mathrm{KW}(\mathrm{H})$ & $\mathrm{KW}(\mathrm{p})$ \\
\hline \multirow[b]{2}{*}{ Gender } & male & 3.74 & \multirow[b]{2}{*}{0.400} & \multirow[b]{2}{*}{0.527} \\
\hline & female & 3.78 & & \\
\hline \multirow{4}{*}{ Class } & 1. class & 3.80 & \multirow{4}{*}{1.892} & \multirow{4}{*}{0.595} \\
\hline & 2. class & 3.74 & & \\
\hline & 3. class & 3.85 & & \\
\hline & 4. class & 3.67 & & \\
\hline \multirow{3}{*}{ Environment } & urban & 3.79 & \multirow{3}{*}{1.576} & \multirow{3}{*}{0.455} \\
\hline & suburban & 3.68 & & \\
\hline & rural & 3.85 & & \\
\hline
\end{tabular}

By analyzing the responses of male students (3.61) and female students (3.41), there are no statistically significant differences in the consumption of bread, dough and pastry. In the answers of students of the first class (3.61), second class (3.49), third class (3.66) and fourth class (3.56) there are no statistically significant differences. In the answers of students from the urban environment (3.58), from the suburban environment (3.62), and the rural environment (3.51) there are no statistically significant differences. (Table 6).

Table 6. Odgovori učenika o konzumiranju hleba, testa i peciva prema polu, razredu i sredini iz koje dolaze učenici

\begin{tabular}{|c|c|c|c|c|}
\hline \multicolumn{5}{|c|}{ How much do you eat bread, dough and pastries? } \\
\hline & & Mean & $\mathrm{KW}(\mathrm{H})$ & $\mathbf{K W}(\mathbf{p})$ \\
\hline \multirow[b]{2}{*}{ Gender } & male & 3.61 & \multirow[b]{2}{*}{0.565} & \multirow[b]{2}{*}{0.452} \\
\hline & female & 3.41 & & \\
\hline \multirow{4}{*}{ Class } & 1. class & 3.61 & \multirow{4}{*}{1.114} & \multirow{4}{*}{0.767} \\
\hline & 2. class & 3.49 & & \\
\hline & 3. class & 3.66 & & \\
\hline & 4. class & 3.56 & & \\
\hline
\end{tabular}




\begin{tabular}{|c|c|c|c|c|}
\hline \multirow{2}{*}{ Environment } & urban & 3.58 & \multirow{2}{*}{} \\
\cline { 2 - 3 } & suburban & 3.62 & \multirow{2}{*}{0.672} & 0.715 \\
\cline { 2 - 3 } & rural & 3.51 & & \\
\hline
\end{tabular}

Analizom odgovora učenika muškog pola (3.47) i ženskog pola (3.59) postoje statistički značajne razlike u konzumiranju voća i povrća. U odgovorima učenika prvog razreda (3.01), drugog razreda (2.94), trećeg razreda (3.16) i četvrtog razreda (3.04) nema statistički značajnih razlika. U odgovorima učenika iz gradske sredine (3.08), iz prigradske sredine (2.99), i seoske sredine (3.04) postoje statistički značajne razlike (Table 7).

Table 7. Students' responses to the consumption of fruits and vegetables by gender, class, and environment from which they come

\begin{tabular}{|c|c|c|c|c|}
\hline \multicolumn{5}{|c|}{ How much do you consume fruits and vegetables? } \\
\hline & & Mean & $\mathrm{KW}(\mathrm{H})$ & $\mathrm{KW}(\mathrm{p})$ \\
\hline \multirow{2}{*}{ Gender } & male & 3.47 & \multirow{2}{*}{0.655} & \multirow{2}{*}{0.418} \\
\hline & female & 3.59 & & \\
\hline \multirow{4}{*}{ Class } & 1. class & 3.59 & \multirow{4}{*}{5.389} & \multirow{4}{*}{0.146} \\
\hline & 2. class & 3.73 & & \\
\hline & 3. class & 3.45 & & \\
\hline & 4. class & 3.33 & & \\
\hline \multirow{3}{*}{ Environment } & urban & 3.58 & \multirow{3}{*}{6.214} & \multirow{3}{*}{0.045} \\
\hline & suburban & 3.62 & & \\
\hline & rural & 3.51 & & \\
\hline
\end{tabular}

By analyzing the responses of male students (4.07) and female students (3.94), there are no statistically significant differences in the consumption of cakes and sweets. In the answers of the students of the first class (4.14), the second class (3.96), the third class (4.03) and the fourth class (3.90) there are no statistically significant differences. There are no statistically significant differences in the answers of students from the urban environment (3.96), from the suburban environment (3.96), and the rural environment (3.92) (Table 8). 
Table 8. Answers of students about consuming cakes and sweets by gender, class, and environment from which they come

\begin{tabular}{|c|c|c|c|c|}
\hline \multirow{4}{*}{ Gender } & & Mean & KW(H) & KW(p) \\
\hline \multirow{4}{*}{ Class } & male & 4.07 & \multirow{2}{*}{1.434} & 0.231 \\
\cline { 2 - 3 } & female & 3.94 & & \\
\hline \multirow{4}{*}{} & 1. class & 4.14 & & \multirow{2}{*}{0.541} \\
\cline { 2 - 3 } & 2. class & 3.96 & \multirow{2}{*}{2.154} & \\
\cline { 2 - 3 } & 3. class & 4.03 & & \multirow{2}{*}{0.570} \\
\cline { 2 - 3 } & 4. class & 3.90 & & \\
\hline \multirow{3}{*}{ Environment } & urban & 3.96 & & \\
\cline { 2 - 3 } & suburban & 3.96 & \multirow{2}{*}{1.125} & \\
\cline { 2 - 3 } & rural & 3.92 & & \\
\hline
\end{tabular}

By analyzing the responses of male students (3.34) and female students (3.29) there are statistically significant differences in the consumption of water and fruit juices. In the answers of students of the first class (3.10), second class (3.41), third class (3.29) and fourth class (3.14) there are no statistically significant differences. In the answers of students from the urban environment (3.25), from the suburban environment (3.32), and the rural environment (3.40) there are no statistically significant differences (Table 9).

Table 9. Answers of students about consuming water and fruit juices by gender, class and environment from which they come

\begin{tabular}{|c|c|c|c|c|}
\hline \multicolumn{5}{|c|}{ How much do you consume water and fruit juices? } \\
\hline \multirow{3}{*}{ Gender } & & Mean & KW(H) & KW(p) \\
\hline \multirow{5}{*}{ Class } & male & 3.34 & \multirow{2}{*}{0.270} & 0.603 \\
\cline { 2 - 3 } & female & 3.29 & & \\
\hline & 1. class & 3.10 & & \multirow{2}{*}{0.352} \\
\cline { 2 - 3 } & 2. class & 3.41 & \multirow{2}{*}{3.272} & \\
\cline { 2 - 3 } & 3. class & 3.29 & & \multirow{2}{*}{0.710} \\
\cline { 2 - 3 } & 4. class & 3.14 & & \\
\hline \multirow{7}{*}{ Environment } & urban & 3.25 & & \\
\cline { 2 - 3 } & suburban & 3.32 & \multirow{2}{*}{0.685} & \\
\cline { 2 - 3 } & rural & 3.40 & & \\
\hline
\end{tabular}


By analyzing the responses of male students (3.91) and female students (3.78) there are statistically significant differences in the consumption of energy and carbonated drinks. In the answers of the students of the first class (4.06), the second class (3.82), the third class (3.88) and the fourth class (3.62) there are no statistically significant differences. In the answers of students from the urban environment (3.83), from the suburban environment (3.78) and rural areas (3.92) there are no statistically significant differences (Table 10).

Table 10. Answers of students about consuming energy and carbonated drinks by gender, class and environment from which they come

\begin{tabular}{|c|c|c|c|c|}
\hline \multicolumn{5}{|c|}{ How much do you consume energy and carbonated drinks? } \\
\hline \multirow{4}{*}{ Gender } & & Mean & KW(H) & KW(p) \\
\hline & male & 3.91 & \multirow{2}{*}{0.510} & \multirow{2}{*}{0.475} \\
\cline { 2 - 3 } & female & 3.78 & & \\
\hline \multirow{5}{*}{ Class } & 1. class & 4.06 & & \multirow{2}{*}{0.215} \\
\cline { 2 - 3 } & 2. class & 3.82 & \multirow{2}{*}{4.467} & \\
\cline { 2 - 3 } & 3. class & 3.88 & & \multirow{2}{*}{0.977} \\
\cline { 2 - 3 } & 4. class & 3.62 & \\
\hline \multirow{4}{*}{ Environment } & urban & 3.83 & \multirow{2}{*}{0.047} & \\
\cline { 2 - 3 } & suburban & 3.78 & & \\
\cline { 2 - 3 } & rural & 3.92 & & \\
\hline
\end{tabular}

In Figure 1. graphs show the percentage values of all pupils on eating habits of each investigated food group.

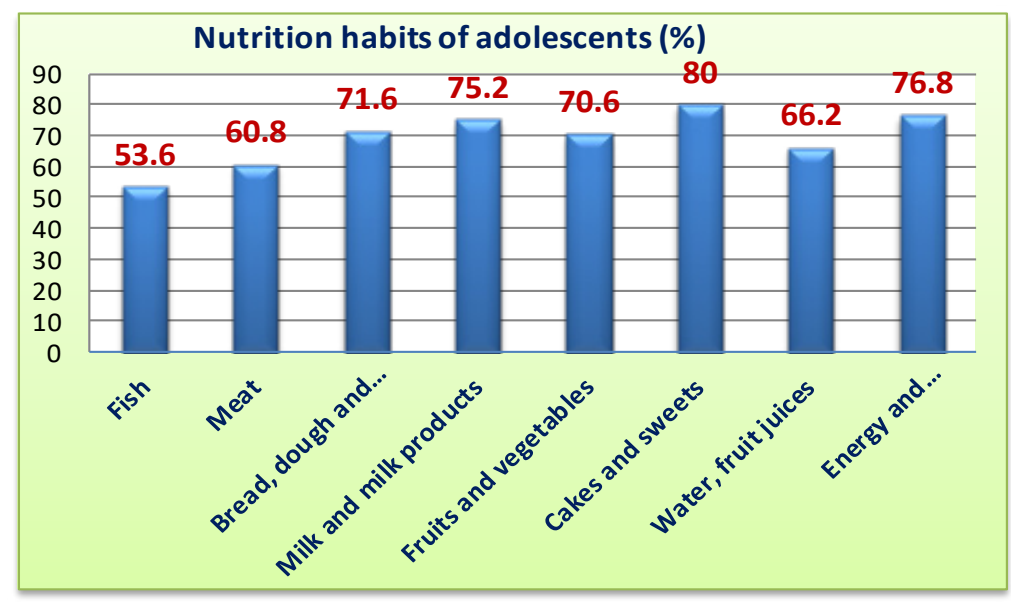

Figure 1. Eating habits of adolescents by groups of foods tested. 
The third group of questions was related to diet. By analyzing the responses of male students (3.73) and female students (3.61), there are no statistically significant differences in nutrition in the home or outside. In the answers of the students of the first class (3.85), the second class (3.69), the third class (3.38) and the fourth class (3.71) there are no statistically significant differences. In the answers of students from the urban environment (3.72), from the suburban environment (3.41), and the rural environment (3.94) there are statistically significant differences (Tabela 11).

Table 11. Answers of students about diet by gender, class and environment from which they come

\begin{tabular}{|c|c|c|c|c|}
\hline \multicolumn{5}{|c|}{ Do you eat more in the house than outdoors? } \\
\hline & & Mean & $\mathrm{KW}(\mathrm{H})$ & $K W(p)$ \\
\hline \multirow[b]{2}{*}{ Gender } & male & 3.73 & \multirow[b]{2}{*}{0.536} & \multirow[b]{2}{*}{0.215} \\
\hline & female & 3.61 & & \\
\hline \multirow{4}{*}{ Class } & 1. class & 3.85 & \multirow{4}{*}{6.577} & \multirow{4}{*}{0.087} \\
\hline & 2. class & 3.69 & & \\
\hline & 3. class & 3.38 & & \\
\hline & 4. class & 3.71 & & \\
\hline \multirow{3}{*}{ Environment } & urban & 3.72 & \multirow{3}{*}{6.266} & \multirow{3}{*}{0.044} \\
\hline & suburban & 3.41 & & \\
\hline & rural & 3.94 & & \\
\hline
\end{tabular}

By analyzing students' responses to the existence of health problems or hereditary diseases, there are no statistically significant differences among male students (1.59) and female students (1.68). In the answers of the students of the first class (1.68), the second class (1.73), the third class (1.56) and the fourth class (1.64) there are no statistically significant differences. In the answers of students from the urban environment (1.73), from the suburban environment (1.64) and the rural environment (1.52) there are no statistically significant differences (Table 12).

Tabela 12. Student's responses to health problems or hereditary diseases by gender, class and environment from which they come

\begin{tabular}{|c|c|c|c|c|}
\hline \multicolumn{5}{|c|}{ Do you have health problems or inherited diseases? } \\
\hline \multirow{2}{*}{ Gender } & & Mean & $\mathrm{KW}(\mathrm{H})$ & $\mathrm{KW}(\mathrm{p})$ \\
\hline & male & 1.59 & & \\
\cline { 2 - 4 } & female & 1.68 & 0.739 & 0.390 \\
\hline
\end{tabular}




\begin{tabular}{|c|c|c|c|c|}
\hline \multirow{4}{*}{ Class } & 1. class & 1.73 & \multirow{4}{*}{0.453} & \multirow{4}{*}{0.929} \\
\hline & 2. class & 1.56 & & \\
\hline & 3. class & 1.65 & & \\
\hline & 4. class & 1.64 & & \\
\hline \multirow{3}{*}{ Environment } & urban & 1.73 & \multirow{3}{*}{0.090} & \multirow{3}{*}{0.956} \\
\hline & suburban & 1.64 & & \\
\hline & rural & 1.52 & & \\
\hline
\end{tabular}

By analyzing students' responses regarding diet, among male students (1.62) and female students (2.04), there are statistically significant differences. In the answers of students of the first class (2.04), second class (1.80), third class (1.72) and fourth class (1.87) there are no statistically significant differences. There are no statistically significant differences in the answers of students from the urban environment (1.87), from the suburban environment (1.87), and the rural environment (1.77 (Table 13).

Table 13. Answers of students about diet by gender, class and environment from which they come

\begin{tabular}{|c|c|c|c|c|}
\hline \multicolumn{5}{|c|}{ Da li ste nekada držali dijetu? } \\
\hline & & Mean & $\mathrm{KW}(\mathrm{H})$ & $\mathrm{KW}(\mathrm{p})$ \\
\hline \multirow[b]{2}{*}{ Gender } & male & 1.62 & \multirow{2}{*}{10.436} & \multirow{2}{*}{0.001} \\
\hline & female & 2.04 & & \\
\hline \multirow{4}{*}{ Class } & 1. class & 2.04 & \multirow{4}{*}{3.713} & \multirow{4}{*}{0.294} \\
\hline & 2. class & 1.80 & & \\
\hline & 3. class & 1.84 & & \\
\hline & 4. class & 1.72 & & \\
\hline \multirow{3}{*}{ Environment } & urban & 1.87 & \multirow{3}{*}{0.771} & \multirow{3}{*}{0.680} \\
\hline & suburban & 1.87 & & \\
\hline & rural & 1.77 & & \\
\hline
\end{tabular}

By analyzing students' responses to the effect of diets on health, there are no statistically significant differences between male students (2.54) and female students (2.55). In the answers of students of the first class (2.56), second class (2.61), third class (2.42) and fourth class (2.58) there are no statistically significant differences. In the answers of students from the urban environment (2.53), there are no statistically significant differences from the suburban environment (2.48) and the rural environment (2.67) (Table 14). 
Table 14. Answers of students about diet by gender, class and environment from which they come

\begin{tabular}{|c|c|c|c|c|}
\hline \multicolumn{5}{|c|}{ Do you think the diet affects health? } \\
\hline & & Mean & $\mathrm{KW}(\mathrm{H})$ & $\mathrm{KW}(\mathrm{p})$ \\
\hline \multirow[b]{2}{*}{ Gender } & male & 2.54 & \multirow{2}{*}{0.004} & \multirow{2}{*}{0.949} \\
\hline & female & 2.55 & & \\
\hline \multirow{4}{*}{ Class } & 1. class & 2.56 & \multirow{4}{*}{4.467} & \multirow{4}{*}{0.215} \\
\hline & 2. class & 2.61 & & \\
\hline & 3. class & 2.42 & & \\
\hline & 4. class & 2.58 & & \\
\hline \multirow{3}{*}{ Environment } & urban & 2.53 & \multirow{3}{*}{4.916} & \multirow{3}{*}{0.086} \\
\hline & suburban & 2.48 & & \\
\hline & rural & 2.67 & & \\
\hline
\end{tabular}

By analyzing the student's answer to the question of whether proper diet can alleviate or prevent some diseases, such as diabetes, cholesterol, and others, there are statistically significant differences between male students (4.29) and female students (3.95), namely male students. Conscious that healthy foods can avoid certain diseases. There are statistically significant differences in the answers of the students of the first class (4.46), the second class (4.10), the third class (3.77) and the fourth class (4.12). In the answers of students from the urban environment (4.10), from the suburban environment (4.05), and the rural environment (4.20) there are no statistically significant differences (Table 15).

Table 15. Answers of students about diet by gender, class and environment from which they come

\begin{tabular}{|c|c|c|c|c|}
\hline \multicolumn{5}{|c|}{$\begin{array}{l}\text { Do you think that proper nutrition can alleviate or prevent some diseases such as: diabetes, cholesterol, } \\
\text { and others? }\end{array}$} \\
\hline & & Mean & $\mathrm{KW}(\mathrm{H})$ & $\mathbf{K W}(\mathbf{p})$ \\
\hline \multirow[b]{2}{*}{ Gender } & male & 4.29 & \multirow{2}{*}{6.985} & \multirow{2}{*}{0.008} \\
\hline & female & 3.95 & & \\
\hline \multirow{4}{*}{ Class } & 1. class & 4.46 & \multirow{4}{*}{11.686} & \multirow{4}{*}{0.009} \\
\hline & 2. class & 4.10 & & \\
\hline & 3. class & 3.77 & & \\
\hline & 4. class & 4.12 & & \\
\hline \multirow{3}{*}{ Environment } & urban & 4.10 & \multirow{3}{*}{0.396} & \multirow{3}{*}{0.821} \\
\hline & suburban & 4.05 & & \\
\hline & rural & 4.20 & & \\
\hline
\end{tabular}


By analyzing students' responses to regular breakfast, there are statistically significant differences between male (4.10) and female students (3.80), meaning that male students are more aware that healthy food can avoid certain diseases. There are statistically significant differences in the answers of the students of the first class (4.46), the second class (4.10), the third class (3.77) and the fourth class (4.12). In the answers of students from the urban environment (4.10), from the suburban environment (4.05), and the rural environment (4.20) there are no statistically significant differences (Table 16).

Table 16. Answers of students about diet by gender, class and environment from which they come

\begin{tabular}{|c|c|c|c|c|}
\hline \multicolumn{5}{|c|}{ Do you have regular breakfast? } \\
\hline & & Mean & $\mathrm{KW}(\mathrm{H})$ & $\mathrm{KW}(\mathrm{p})$ \\
\hline \multirow[b]{2}{*}{ Gender } & male & 3.99 & \multirow{2}{*}{6.771} & \multirow{2}{*}{0.009} \\
\hline & female & 3.63 & & \\
\hline \multirow{4}{*}{ Class } & 1. class & 3.74 & \multirow{4}{*}{0.163} & \multirow{4}{*}{0.983} \\
\hline & 2. class & 3.82 & & \\
\hline & 3. class & 3.80 & & \\
\hline & 4. class & 3.81 & & \\
\hline \multirow{3}{*}{ Environment } & urban & 3.93 & \multirow{3}{*}{3.064} & \multirow{3}{*}{0.216} \\
\hline & suburban & 3.82 & & \\
\hline & rural & 3.60 & & \\
\hline
\end{tabular}

The second part of the study was to examine the risk of diabetes type 2, using a standardized questionnaire, which students voluntarily filled out. A total of 111 students, 48 (43.2\%) male, and 63 (56.7\%) females completed the online questionnaire and there were no statistically significant differences in the ratio of male and female respondents in the sample to the risk of diabetes type 2 . The risk results are in degree: low have $79.2 \%$ of students, $14.5 \%$ are in an elevated degree, $2.1 \%$ of students have a moderate risk and $4.2 \%$ are at high risk for type 2 diabetes, while there are no students at very high-risk degree. In low-risk female students are $76.2 \%$ of students, $15.9 \%$ are easily raised, $3.2 \%$ of students have a moderate risk, and $4.7 \%$ have a high risk of type 2 diabetes, while there are no students at very high risk (Table 17). 
Table 17. The results of examining the student's risk of developing type 2 diabetes by gender

\begin{tabular}{|c|c|c|c|c|}
\hline Gender & Percentage & Risk & $\mathrm{KW}(\mathrm{H})$ & $K W(p)$ \\
\hline \multirow{5}{*}{$\begin{array}{c}\text { male } \\
(48) \\
(43.2 \%)\end{array}$} & 79.2 & Low & \multirow{10}{*}{2.027} & \multirow{10}{*}{0.155} \\
\hline & 14.5 & Easy elevated & & \\
\hline & 2.1 & Moderate & & \\
\hline & 4.2 & High & & \\
\hline & 0.0 & Very high & & \\
\hline \multirow{5}{*}{$\begin{array}{c}\text { female } \\
(63) \\
(56.7 \%)\end{array}$} & 76.2 & Low & & \\
\hline & 15.9 & Easy elevated & & \\
\hline & 3.2 & Moderate & & \\
\hline & 4.7 & High & & \\
\hline & 0.0 & Very high & & \\
\hline
\end{tabular}

Measured values of BMI greater than 30 are found in $6.2 \%$ of male students and $7.9 \%$ female students, values between 25 and 30 are $14.6 \%$ of male students and $22.2 \%$ female, and with less than 25 , the vast majority is $79.2 \%$ male students and $69.9 \%$ female students. Measured values of the volume of waist greater than 102 are found in $6.2 \%$ of male students, values between 94 and 102 are found in $14.6 \%$ of students, and with less than 94 , the vast majority are $79.2 \%$ of students. Measured values of the volume of waist greater than 88 are found in $7.9 \%$ female students, values between 80 and 88 are found in $7.9 \%$ female students, and with a smaller than 80 , the vast majority are $79.4 \%$ of students. There are no statistically significant differences in BMI values and measured values of waist circumference for male and female students (Table 18).

Table 18. Percentage of students according to BMI and waist size by gender

\begin{tabular}{|c|c|c|c|c|c|c|}
\hline \multirow{4}{*}{ male } & $\begin{array}{c}\text { BMI } \\
(\%)\end{array}$ & \multicolumn{2}{|c|}{ Values } & $\begin{array}{c}\text { Waist size } \\
(\%)\end{array}$ & \multicolumn{2}{c|}{ Values } \\
\hline \multirow{4}{*}{} & 6.2 & $>30$ & 3 & 6.2 & $>102$ & 4 \\
\cline { 2 - 7 } & 14.6 & $25-30$ & 1 & 14.6 & $94-102$ & 3 \\
\cline { 2 - 7 } & 79.2 & $<25$ & 0 & 79.2 & $<94$ & 0 \\
\hline \multirow{4}{*}{ female } & 7.9 & $>30$ & 3 & 7.9 & $>88$ & 4 \\
\cline { 2 - 7 } & 22.2 & $25-30$ & 1 & 12.7 & $80-88$ & 3 \\
\hline \multirow{4}{*}{} & 69.9 & $<25$ & 0 & 79.4 & $<80$ & 0 \\
\hline & $\mathrm{KW}(\mathrm{H})$ & $\mathrm{KW}(\mathrm{p})$ & & $\mathrm{KW}(\mathrm{H})$ & $\mathrm{KW}(\mathrm{p})$ & \\
\hline & 0.318 & 0.573 & & 0.000 & 0.983 & \\
\hline
\end{tabular}


The percentage of students who used antihypertensive drugs was $4.2 \%$ for males, $3.2 \%$ for females, and those who did not use antihypertensive drugs in male was $95.8 \%$ and for females $96.8 \%$. The percentage of students in whom elevated sugar is measured is in the male ratio of $4.2 \%$, in the female half $4.8 \%$, and those who have not measured the elevated sugar in the male is $95.8 \%$, the female is $95.2 \%$. There are no statistically significant differences in the percentage of students using antihypertensive drugs, nor in the percentage of students in whom elevated sugar is measured, depending on males and females (Table 19).

Table 19. Percentage of students who use antihypertensive drugs and students who measured the value of sugar by sex

\begin{tabular}{|c|c|c|c|c|c|c|}
\hline \multirow{2}{*}{ male } & Antihypertensive (\%) & \multicolumn{2}{|c|}{ Values } & \multicolumn{2}{c|}{$\begin{array}{c}\text { Sugar } \\
(\%)\end{array}$} & \multicolumn{2}{c|}{ Values } \\
\cline { 2 - 7 } & 4.2 & $\mathrm{Da}$ & 2 & 4.2 & $\mathrm{Da}$ & 5 \\
\hline \multirow{3}{*}{ female } & 95.8 & $\mathrm{Ne}$ & 0 & 95.8 & $\mathrm{Ne}$ & 0 \\
\cline { 2 - 7 } & 3.2 & $\mathrm{Da}$ & 2 & 4.8 & $\mathrm{Da}$ & 5 \\
\hline & 96.8 & $\mathrm{Ne}$ & 0 & 95.2 & $\mathrm{Ne}$ & 0 \\
\hline & $\mathrm{KW}(\mathrm{H})$ & $\mathrm{KW}(\mathrm{p})$ & & $\mathrm{KW}(\mathrm{H})$ & $\mathrm{KW}(\mathrm{p})$ & \\
\hline & 0.022 & 0.881 & & 0.076 & 0.782 & \\
\hline
\end{tabular}

The greatest impact of hereditary risk factors for diabetes mellitus type 2 in male students from the immediate family is $16.7 \%$, and female students $7.9 \%$. The impact of hereditary factors from members of the wider family in male students is $18.8 \%$, and female students $12.7 \%$. Without the influence of hereditary factors, $64.5 \%$ of male students and $79.4 \%$ of female students is probability (Table 20 ).

Table 20. Percentage of students with inherited risks of type 2 diabetes by gender

\begin{tabular}{|c|c|c|c|c|c|}
\hline \multirow{4}{*}{ male } & $\begin{array}{c}\text { Hereditary factors } \\
\text { (\%) }\end{array}$ & \multicolumn{2}{|c|}{ Points } & \multirow{2}{*}{ KW(H) } & \multirow{2}{*}{ KW(p) } \\
\cline { 2 - 4 } & 16.7 & Yes (close family) & 5 & & \\
\hline \multirow{3}{*}{ female } & 18.8 & Yes (whole family) & 3 & & \\
\cline { 2 - 4 } & 64.5 & No & 0 & \multirow{2}{*}{3.173} & \multirow{2}{*}{0.075} \\
\cline { 2 - 4 } & 7.9 & Yes (close family) & 5 & \\
\hline
\end{tabular}




\section{CONCLUSION}

Analyzing the eating habits of adolescents, it can be concluded that they do not differ too much, depending on half of the students. (15) Fewer gender differences exist in the habits of certain foods. From the previous analysis, it can be concluded that male students consume more meat by about $7.5 \%$ compared to female students. Also, female students by $8.3 \%$ more hold the child than male students. Male pupils by $7.2 \%$ more often have breakfast than female students. Observed in the center from which they come, fish are mostly consumed by students from the suburban environment by $8 \%$ more than in urban and rural areas. Fruits and vegetables are about $2.5 \%$ more consumed by students from the suburban environment than from urban and rural areas. The largest percentage of $10 \%$ of rural students consumes food at home, compared to students in urban and suburban environments. While differences in attitudes about the impact of proper nutrition on the emergence of chronic non-communicable diseases differ in both the sex and the meanings from which they come. (16), (17) Our assumed assumption is not sustainable, and we accept the alternative hypothesis of the first hypothesis $\mathrm{H} 1$.

General habits in the adolescent diet are not the best because they consume: cakes and sweets $80 \%$, energy and carbonated drinks $76.8 \%$, bread and pastry bread $71.6 \%$ (Figure 1). The results of the standardized questionnaire show that $4.2 \%$ of male students and $4.7 \%$ of female students at high risk for type 2 diabetes. (18) At moderate risk, $2.1 \%$ are male and $3.2 \%$ female students. In an increased risk, $14.5 \%$ of male students and $15.9 \%$ of female students (Table 15 ).

Taking into account eating habits and current results of risk assessment for diabetes in students aged 14 to 18 , preventive action is necessary, (19) in order to reduce the risk and mitigate as much as possible (14). We can confirm the implied assumption that the risk of developing type 2 diabetes in both males and females is lower than $15 \%$ and that the $\mathrm{H} 2$ hypothesis can be accepted.

It is necessary to suggest to students who are at a high and moderate risk of doing the OGTT test in order to eliminate or confirm the above-mentioned concerns about diabetes. (20), (21) All students should be introduced to the consequences of improper diet and diseases that can arise as their consequence.

\section{References}

1. M. Dokić, M. Jevtić, D. Balać, Prevention of type 2 diabetes mellitus in children and adolescents, Medical Bulletin, 1452-09231141050D, 2011.

2. Ž. Lalić, K. Rašković, Risk assessment for diabetes mellitus type 2 in health care workers, General medicine, UDC 616.379-008.64-05, 716(3-4);138-142, 2010. 
3. Incidence and Mortality from Diabetes in Serbia, Institute of Public Health „Milan Jovanović Batut, 2017.

4. MedicineWorld.Org - Endocrinology-Type 2 diabetes, Your gateway to information on type 2 diabetes; http://www.medicineworld.org/medicine/endocrinology/type2diabetes. html

5. M. Dumić, A. Š. Uroić, Diabetes mellitus in adolescents, Pediatric Clinic of the Faculty of Medicine, University of Zagreb, KBC Zagreb, MEDICUS 2010; Vol. 19, No. 1, $27-34$.

6. R. Vuković, D. Zdravković. Frequency of glucose regulation in obese children adolescents in Serbia. Medical Bulletin Special Hospital for thyroid gland diseases metabolism. Zlatibor 2012; 17: 92-105.

7. G. Švonja-Parezanović, B. Perić-Prkosovački, Nutrition and habits in the diet of young people. PONS Med čas, 2014; 11: 48-52.

8. G. Bukara-Radujković, D. Zdravković, Determinants of obesity in children and adolescents. Srp Arh Celok Lek 2008; 136: 22-7.

9. About BMI for Children and Teens. Atalanta: Centers for Disease Control and Prevention, 2015. http://www.cdc.gov/healthyweight/assessing/bmi/childrens_bmi/about_childrens_bmi.html

10. SR. Daniels, DK. Arnett, RH. Eckel, et al. Overweight in children and adolescents: pathophysiology, consequences, prevention, and treatment. Circulation 2005; 111: 1999-2002.

11. The Diabetes Control and Complications Trial Research Group. The absence of aglycaemic treshold for the development of long-term complications: the perspective of DCCT. Diabetes 1996; 45: 1289-98.

12. SPSS Statistical, available: https://www.ibm.com/products/spss-statistics.

13. Working in SPSS, available: http://stat.uns.ac.rs/LLLprogramme/NP/TeachingMaterial/ Uputstvo.pdf

14. I. Jevtović, Medicinska statistika. Kragujevac: Medicinski fakultet, 2008.

15. American Diabetes Association: Type 2 diabetes in children and adolescents. American Diabetes Association. Pediatrics 2000;105: 671-80.6.

16. F. Chiarellif, C. Giannini, A. Mohn A., Growth, growth factors and diabetes. Eur J Endocrinol. 2004;151 (Suppl 3): U109-17.

17. J. Lebl, E. Schober, T. Zidek et al., Growth data in large series of 587 children and adolescents with type 1 diabetes mellitus. Endocr Regul 2003; 37: 153-61.

18. Cl. Cacerinini, RM. Williams, DB, Dunger, Metabolic impact of puberty on the course of type 1 diabetes. Diabetes Metab 2001; 27: S19-25.

19. Y. Xin, A. Davies, L. McCombie, A. Briggs, CM Messow, E. Grieve, et al., Type 2 diabetes remission: economic evaluation of the DiRECT/Counterweight-Plus weight management programme within a primary care randomized controlled trial, Med. 2019. doi: $10.1111 / \mathrm{dme} .13981$

20. Z. Liu, C. Fu, W. Wang, B.Xu, Prevalence of chronic complications of type 2 diabetes mellitus in outpatients - a crosssectional hospital based survey in urban China. Health Qual Life Outcomes 2010; 8: 62. 
21. WC. Chumlea, CM. Schubert, AF. Roche et al, Age at menarche and racial comparisons in US girls. Pediatrics. 2003; 111: 110-3.

22. B. Anderson, J. Ho, J. Brackett, D. Finkelstein, L. Laffel, Parental involvement in diabetes management tasks: relationships to blood glucose monitoring adherence and metabolic control in young adolescents with insulin-dependent diabetes mellitus. J Pediatr 1997; 130: $257-65$. 